\title{
Potential Use of Entomopathogenic Virus Native to Sumatra Island as Biological Control Agent of Setora nitens L. (Lepidoptera:Limacodidae), the Main Pest of Oilpalm
}

\author{
Suparman", Yulia Pujiastuti", Hisanori Bando*, Shin-ichiro Asano* \\ \# Department of Plant Pests and Diseases, University of Sriwijaya, Inderalaya, Ogan Ilir,30662,Indonesia \\ E-mail: suparmanshk@gmail.com,yulunsri@yahoo.com \\ * Hokkaido University, Kita-ku, Kita 9, Nishi 9, Sapporo 060-8589, Japan \\ E-mail: hban@abs.agr.hokudai.ac.jp, sangaku@abs.agr.hokudai.ac.jp
}

\begin{abstract}
Slug caterpillars Setora nitens, have been appearing to be more serious insect pest of oil palm as it might cause frond damages up to $90 \%$. Many effort had been made to control the caterpillars using insecticides but the insects are still existing and causing significant damages to the palm. Microbial insecticide, especially the one developed from indigenous entomopathogenic virus, is a promising method of controlling the insect since its toxicity to non target animals and humans is extremely low. A conventional way of controlling $S$. nitens using crude sap of infected larvae has been applied in several oil palm plantations in Sumatra Island, but various improvements are required to make the method more effective, efficient, widely acceptable and scientifically justified. A research on the potential use of entomopathogenic virus native to Sumatra Island as biological control agent of slug caterpillar was conducted to comprehend the pathogenicity and virulence of the entomopathogenic virus and to reveal the morphological identify of its particle. The results showed that the use of virus infecting caterpillars to control the insect was quite successful in term of increasing the number of infected caterpillars and reducing the rate of population development in the field. The use of homogenized infected caterpillars to orally infect healty $S$. nitens caterpillars resulted in the symptoms characteristics to viral infections appeared in all treated caterpillars with various extent of symptom developments. Some caterpillars could spine cocons but failed to release adult moth. Purification of the virus particles from infected caterpillars resulted in the apperarance of white band in the sucrose gradient indicated the presence of viral RNA. Electron microscopic observation showed that the white band in the sucrose gradient contained sphericle shape of virus particles justifying that the agent infecting $\mathbf{S}$. nitens caterpillars is a virus which still need further analysis for its complete identification.
\end{abstract}

Keywords - Entomopathogenic Virus; Oilpalm; Setora Nitens.

\section{INTRODUCTION}

The cultivation of oil palm in Indonesia was started in Sumatra before finally spread to other big islands such as Kalimantan, Sulawesi and Papua. Major palm oil producing provinces in Sumatra are Riau, North Sumatra, SouthSumatra, Jambi and Lampung. There had been major challenges in the development of oil palm plantation in Indonesia, such as good governance and investment, leadership, land policy, regional autonomy and labor.

Furthermore, oil palm growing areas have potential insect pests such as rhinoceros beetle, scale insect, bagworms, slugcaterpillar, cutworm, leaf miner moths, bunch moth, leafhopper, aphids, and mealy bugs. Slug caterpillars, especially Darna trima, Setothosea assigna and Setora nitens, have been appearing to be more serious insect pest of oil palm[1]. Many effort had been made to control the caterpillars using insecticides but the insects are still existing and causing significant damages to the palm. Furthermore, as suggested by [2], the application of insecticide may cause a lot of disadvantages described as environmental and economic costs.

One constraint to produce high quality and quantity of oil palm is a main insect pest, Setora nitens (Lepidoptera: Limacodidae), slug caterpillars on the leaves of mature and immature palms [3], [4]. S. nitens together with Darna trima, D. bradleyi, and Setothosea asigna are also called as nettle caterpillars and are important defoliators of oil palm plantations in southeast Asia [5]. In severe infestations, larvae consume all foliage and leave only the mid-rib of the frond, which might cause significant decrease of fruit production [6] . Crop losses caused by the insect feeding on oil palm leaves have been calculated to be about $30 \%$ of the crop yield [7], [8]. The serious damage caused by S. nitens 
and the potential yield losses seems to be an acceptable reason for oil palm grower to use insecticides to control the pest.

Controling the outbreaks of S. nitens, and other limacodids attacking oil palm, inavitably provoked the applications of broad spectrum insecticides which might cause serious damages to the environment [9], [10], [11], [12]. The consequences of the application of this technique was apparent: pollution, toxicity to human and domestic animal, development of resistant pest population, damage to beneficial insect and the development of new pest [13]. Furthermore, since not all chemical substances have always been used correctly and some of them are particularly highly toxic, non target insects such as natural enemies sometimes are being poisoned. Synthetic insecticide has been reported to cause resistance phenomena, very wide spread pollution and sometimes caused serious imbalances within ecosystems [2].

Demand for effective and safer pesticides under sustainable agriculture system has push the search for biological pesticide. As an organism, insects are subject to diseases caused by viruses, bacteria, and fungi. A considerable number of bioinsecticides have reached the market place, and million of hectares are treated annually with entomopathogenic microorganisms worldwide [14]. Despite recent advances, the use of bioinsecticide is proportionally limited when compared to their chemical counterparts, even in countries where many biopesticides are produced.

The growing adoption of microbial biocontrol agents depends on factors such as: 1) development of better products, 2) development and implementation of truly integrated pest management strategies in which biological option are emphasized [15], [16], [17], 3) the capacity of biopesticide manufacturers to maintain marketing and product support teams, 4) cultural changes (acceptance by farmers of slow-acting narrow-host-range product), and 5) knowledge-based recommendations for product use[18] .

Most insect pathogens, especially entomopathogenic baculovirus, tend to infect primarily insect larvae and are only effective against this stage. Some of identifiedbaculovirus have been successfully used as biological control of insect pest. For example, baculoviruses has been used to control velvet bean caterpillar (Anticarsia genzmatalis) on soybean in Brazil [19]. The virus are often specific, safe for human and other vertebrate and have little or no environmental impact.

A major drawback of baculoviruses is the long incubation period to show effect or cause disease. Their action is relatively slow (a matter of days or weeks) when compared to most chemical insecticides (<day). However, improvement of the speed of kill of certain baculovirus has been achieved either by strain selection or by genetic engineering of Spodoptera exigua multicapsid nucleopolyhedrovirus (SeMNPV) [20]. Genetic engineering approaches have also been used predominantly to increase the speed of action such as deletion of specific gene or insertion of various insect-specific toxin genes [21], [22], [23].

Another successful application of baculovirus has been the control of coconut rhinoceros beetle (Oryctes rhinoceros) in the Andaman Islands in India. Virus epidemics in beetle populations was induced by infecting and liberating beetles with Oryctes baculovirus. Results comparing levels of beetle damage to coconut, before and after virus introductions, have been $80-90 \%$ reductions.

Recently, an unidentified virus was found infecting Setora nitens and there have been an outlook to use the virus as a biological control agent of the insect. Trials had been made to spray crude sap of the infected caterpillar to the caterpillar population and the result were promising. However, very few of the virus characteristic are known and there is obviously a need to study the rest characteristics when the optimal use of the virus as biological control agent is under consideration.

The pathogenicity and virulence of the virus had not been thoroughly understood. Molecular characterization of an unidentified entomopathogenic virus is anotehr very important aspect because it will provide definitive identities of the virus.

\section{MATERIALS AND METHODS}

The experiment was conducted in the Laboratory of Phytopahology, Department of Plant Pests and Diseases Faculty of Agriculture, Sriwijaya University in November 2012. The Setora nitens caterpillar used for bioassay test were collected from PT Salim Oil Palm Plantation, Pekan Baru, Riau. Only fresh and healty fifth instar caterpillar were used in the experiment.

The lates larval stage was selected because the caterpillars of this stage are very greedy, consuming large amount of leaves as preparation for their pupal stadia. 100 grams of infected caterpillars newly collected from sprayed field were homogenized and disolved in 5000 water. The use of less amount of water compared to that used by oil palm growers was to guarentee that there are enough virus in the suspension to infect healthy caterpillars.

Leaf blads from midlle frond of oil palm were cut into 25 $\mathrm{cm}$ long segments and dipped into the suspension. The wet leaf segments were then place in a $40 \times 60 \times 30 \mathrm{~cm} 3$ box to feed 100 caterpillars. The leaves segments were replaced whenever necessary, to increasethe appetite of the caterpillars.

Observation was conducted daily to record the incubation period, infection frequency, cocoon formation, disease symptoms, adult moth liberation and mortality. To purify virus infecting S. nitens caterpillar, 200 gr of frozen larvae (kept in $-80 \mathrm{oC}$ freezer) were thawed and homogenized in $500 \mathrm{ml}$ of extraction buffer containing $50 \mathrm{mM}$ Tris/ $\mathrm{HCl}, 1$ mM EDTA with $\mathrm{pH} 7.5$, and $0.2 \%$ 2-mercaptoethanol.

The homogenate was refined by centrifugation at $10,000 \mathrm{xg}$ for 30 minutes, and the supernatant was then centrifuged at $100,000 \mathrm{xg}$ for 3 hours. The pellets were resuspended in $50 \mathrm{ml}$ of $\mathrm{TE}$ buffer containing $50 \mathrm{mM}$ Tris/HCl, and $1 \mathrm{mM}$ EDTA at $\mathrm{pH} 7.5$, layered on TE buffer containing $30 \%$ sucrose $(\mathrm{w} / \mathrm{v})$, and then centrifuged at $100,000 \mathrm{xg}$ for $3 \mathrm{~h}$. The pellets were resuspended in $5 \mathrm{ml}$ of TE buffer and subjected to further purification by a sucrose gradient and then spun at $100,000 x g$ for $2 \mathrm{~h}$. The sucrose gradient was made by disolving 10, 20, 30 and $40 \%$ sucrose in TE buffer w/v. 
The white band observed in the gradient was collected, centrifuged down at 100,000xg for 3 hours and then resuspended in distilled water. The tentative viral fractions were observed to verify their purity and integrity by negative staining using a transmission electron microscope. Viral particles purified by sucrose gradient centrifugation were negatively stained with $2 \%(\mathrm{w} / \mathrm{v})$ sodium phosphotungstate ( $\mathrm{pH}$ 7.2) on formvar-coated grids, and examined with a transmission electron microscope (Hitachi H-800).

\section{RESULTS AND DISCUSSION}

The caterpillars of S. nites initially fed normally on oil palm leaves wetted with suspension containing the juice of infected caterpillars, but 2 days later their appetite decreased significantly and some caterpillars started to show infection symptoms. The first symptom shown by infected caterpillars was the loss of their appetite, stop feeding, and no response to touch. Infected caterpillars then moved from leaf lamina to midvein and stayed there before finally drop and their color turned to yellowish brown. On the third day, 16 caterpillars showed initial symptom and other symptoms such as moribundity, flaccidity and collapse started to occur on the forth day (Tabel 1). No caterpillars was found dead until the third day, but since the forth day larval mortality start to occur until the ninth day when all caterpillars have died. The slowly infected caterpillars could reach the pupal stage but all of them failed to further develop and died inside the cocoon, no adult moth was released from the cocoons. The incubation period of the virus was determined by - the time period for at least 50 percents of the inoculated caterpillars had shown viral infection symptomsll. As shown in Table 1, the incubation period is 4 days, because in the forth day 53 of 100 inoculated caterpillars have shown various symptoms of infection. This incubation period is smaller than those found in the field which is around 8 days.

The difference was quite acceptable because incubation period of a viral pathogens are dependent upon the viral concentration in the suspension applied and the environmental conditions, especially temperature.

Cocoons were spined by infected caterpillars indicated by the abnormality of the cocoon which was darker in color but no adult moth was released from the cocoon even after 4 weeks, the longest stage of normal cocoons (Table 2). When the cocoon were finally dissected, no cocoon had alive developing moth inside.

The pupae failed to develop and died inside the cocoon. As shown in above table, 39 caterpillars did develope into pupal stage but none of them succesfully developed to become adult moth. The virulence of the virus was indicated by short incubation period and high infection frequency. All caterpillars fed on leaves segment containing the virus were infected and eventually died prematurely.

The high virulence of the virus might be due to several factors such as the viral freshness and particle concentration. The viral freshness was at its optimum because the viruses were harvested from newly infected caterpillars, the moribund caterpillars collected from the area sprayed with suspensions of infected caterpillars from the previous years preserved in a freezer commonly used to preserve food (meet and fish) because the laboratory has not been equipped with technical freezer with very low temperature $(-80 \mathrm{oC})$.
Even though the virus could initiate the disease after being preserved for approximately one year under freezing temperature, the virulence of the virus was lower than that of newly infected caterpillars, indicated by longer incubation period and lower infection frequency. Not all caterpillar fed on sprayed leaves in the field showed viral disease development, many of them escaped from viral infection and survived until the next generations.

This was an indication that virulence of the virus decreased quite significantly after long preservation under freezing temperature. This has proven that the active agent is a virus, because only virus could retain its virulence after being frozen for ling time. However, keeping under freezing temperature for long time also reduced the virulence of the virus. The very high efficacy shown by the mortality of all inoculated caterpillars showed that we can rely on the virus to control the insect, but there must be some adjustment to match the situation in the filed which are very different from those in the experimental situation. The are some important factors to be considered or adjusted to meet the highest efficacy of the viral insecticide to be made based on virus naturally infecting S. nitens. The time of keeping infected caterpillars under freezing temperature and the temperature itself is very influential to the virulence of the virus derived from the insect.

The fresher the better. The concentration of virus particle in the suspension affect the number of virus particles ingested by each caterpillar in a time and this will affect the incubation period and disease development. The spray method or the sprayer used determines the distribution oh the virus particles on the leaf surfaces treated which might cause the same effect as virus concentration.

TABLE I

NUMBER OF CATERPILLARS SHOWING VIRAL INFECTION SYMPTOMS DURING THE FIRST TO FOURT DAY AFTER INOCULATION

\begin{tabular}{|l|c|c|c|c|}
\hline \multirow{2}{*}{ Symptom } & \multicolumn{4}{c|}{ Number of caterpilar showing symptom } \\
\cline { 2 - 5 } & day 1 & day 2 & day 3 & day 4 \\
\hline Active/no symptom & 100 & 100 & 84 & 47 \\
\hline Stop feeding & 0 & 0 & 16 & 34 \\
\hline Flaccidity & 0 & 0 & & 2 \\
\hline Moribundity & 0 & 0 & 0 & 6 \\
\hline Drop & 0 & 0 & 0 & 4 \\
\hline Spine cocoon & 0 & 0 & 0 & 0 \\
\hline Larval mortality & 0 & 0 & 0 & 7 \\
\hline Imago liberation & 0 & 0 & 0 & 0 \\
\hline Total & 100 & 100 & 100 & 100 \\
\hline
\end{tabular}

TABLE II

NUMBER OF CATERPILLARS SHOWING VIRAL INFECTION SYMPTOMS DURING THE FIFTH TO NINTH DAY AFTER INOCULATION

\begin{tabular}{|l|c|c|c|c|c|}
\hline \multirow{2}{*}{ Symptom } & \multicolumn{5}{|c|}{ Number of caterpilar showing symptom } \\
\cline { 2 - 6 } & day 5 & day 6 & day 7 & day 8 & day 9 \\
\hline Active/nosymptom & 18 & 0 & 0 & 0 & 0 \\
\hline Stop feeding & 13 & 18 & 0 & 0 & 0 \\
\hline Flaccidity & 3 & 6 & 0 & 0 & \\
\hline Moribundity & 11 & 7 & 12 & 9 & 0 \\
\hline Drop & 12 & 14 & 11 & 12 & 0 \\
\hline Spine cocoon & 21 & 12 & 6 & 0 & 0 \\
\hline Larval mortality & 15 & 21 & 28 & 10 & 19 \\
\hline Imago liberation & 0 & 0 & 0 & 0 & 0 \\
\hline Total & 93 & 78 & 57 & 29 & 19 \\
\hline
\end{tabular}


The sucrose density gradient centrifugation of pellets suggested containing virus particles resulted six fractions, of which only three fractions showed white bands (fraction 1, 3 and 5) but only. Fraction 5 is the densest and the only one showed molecular weight from the three white bands. When all the six fractions were loaded onto polyacrylamide gel (SDS-Page), fraction 4, 5 and 6 showed similar molecular weight. However, since only faction 5 showed white band, only the white band from fraction 5 was processed for transmission electron microscopy (TEM).

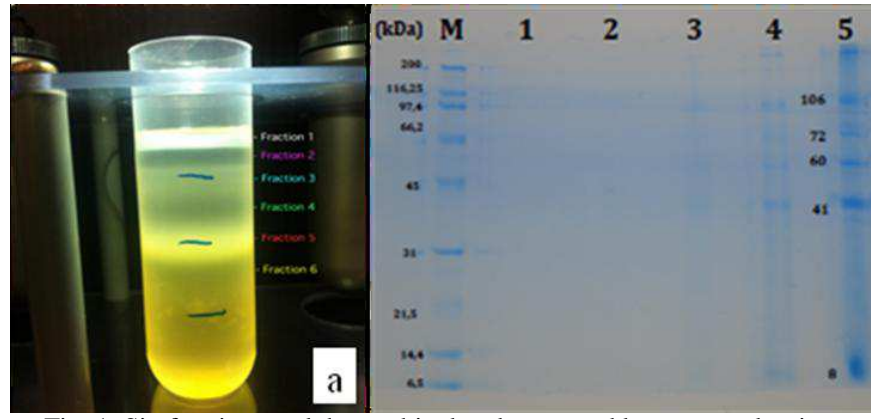

Fig. 1. Six fractions and three white band separated by sucrose density gradient centrifugation (a) and the result of polyacrylamid gel (SDS-Page)

Negative staining revealed that the purified particles had a sphericle shape and no envelope and were about $20 \mathrm{~nm}$ in diamater. This structural traits were similar to thosereported for insect picorna-like viruses and members of the Family Tetraviridae.

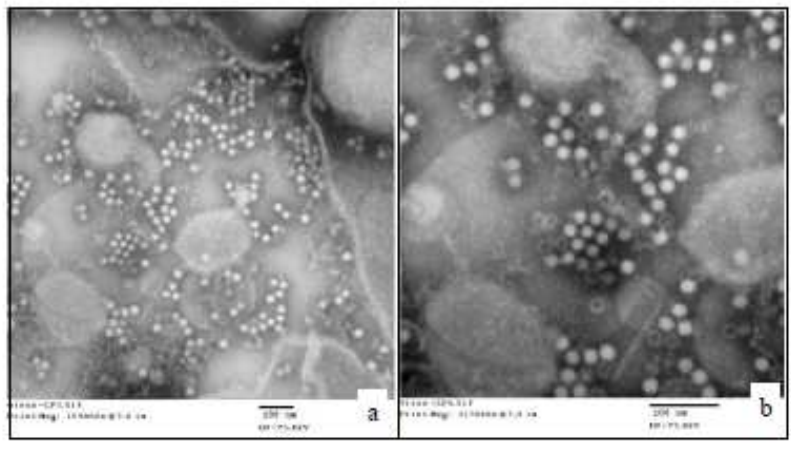

Fig. 2. Negative staining of virus particles purified from Setora nitens by sucrose density gradient centrifugation, photographed from different angle and different magnification

The negative staining clearly showed the spherical or isometric shape form of the virus particle. The absence of capsule and their diameter indicated that the virus is the member of Family Tetraviridae which most of the members are pathogenic to invertebrates. According to International Committee on Taxonomy of Virus (ICTV), virus belong to Tetraviridae are isometric or spherical, have no envelope, infecting invertebrates and have natural genome positivestranded ssRNA.

The first three characteristics match to $\mathrm{S}$. nitens virus, but the genome characteristics have not been studied. Therefore, the virus infecting $\mathrm{S}$. nitens can be tentatively concluded as a member of Family Tetraviridae, but no genus and species can be determined because of the lack information of its genome.

As decided by International Committee on Taxonomy of Virus, many characteristics are required to identify insect viruses. The characteristics required include: biological properties (host range, vectors, mode of transmission), antigenic properties, virion physical/physicochemical characteristics, structural protein characteristics, and genome molecular characteristics.

\section{CONCLUSIONS}

Based on, bioassay experiment and molecular study of the virus naturally infecting Setora nitens of oil palm, it can be concluded that:

1. Virus naturally infecting S. nitens is very promising to be used as biological control agent of the insect. The application of suspension of infected caterpillar juice in clean water is good enough to reach reasonable level of control but there is a need to formulated the standard procedure of making suspension and spraying the suspension.

2. Infected caterpillars kept under freezing temperature can be used as the source of virus, and the virus to some extent can retain its virulence. However, the virus gradually loss its virulence when frozen for long time. Fresh harvested infected caterpillars much more virulence compared to the frozen ones.

3. The purification and transmission electron microscopy of virus naturally infecting $\mathrm{S}$. nitens revealed that the virus is spherical and no envelope. Because the virus infects invertebrate, these three characteristics place the virus in Family Tetraviridae.

\section{REFERENCES}

[1] K. Norman, and M.W. Basri, A survey of current status and control of nettle caterpillars (Lepidoptera: Limacodidae) in Malaysia (19811990). PORIM Occasional paper No. 27: 22pp, 1992.

[2] D. Pimentel, - Environmental and economic costs of the application of pesticides primarily in the United States, \| Environmental Development and Sustainability vol. 7 pp. 229 - 252, 2005.

[3] L.G.E. Kalshoven, The Pest of Crops in Indonesia. PT Ichtiar BaruVan Hoeve, 1981

[4] R.H.V. Corley, and P. B. Tinker.The oil palm. Fourth edition. Blackwell Science, Oxford, UK, 2003.

[5] W. Cock, H.C.J. Godrey, and J.D. Holloway, Slug and nettle caterpillars: The biology,taxonomy and control of the limacodidae of economic importance on palms in South-East Asia. CABI, Oxford, 1987.

[6] H.S. Barlow, An Introduction to the Moths of South East Asia. The Malayan Nature Society,Kuala Lumpur, 1982.

[7] B.J. Wood, R.H.V. Corley, and K.H. Goh. - Studies on the effect of pest damage on oil palm yield $\|$, in R. L. Wastie and D. A. Earp, Ed. Advances in oil palmcultivation. Incorporated Society of Planters, Kuala Lumpur, Malaysia, 1973

[8] A. Dhamayanti, Metode Pengendalian Hama Pemakan Daun, Setora nitens (Limacodidae: Lepidoptera) Menuju Perkebunan Kelapa Sawit Organik. IPB, 2004.

[9] B.J. Wood, C. Hutauruk, S.S. and Liau, - Studies on the chemical and integrated control of nettle caterpillars (Lepidoptera: Limacodidae $\|$, in D. A. Earp and W. Newall, Ed. .International Development in Oil Palms. Incorporated Society of Planters, Kuala Lumpur, 1976.

[10] B.J. Wood, - Economic aspects and chemical control \| in W. Cock, H. C. J. Godfrey, and J. D. Holloway, Ed. Slug and Nettle Caterpillar: The Biology, Taxonomy and Control of the Limacodidae of Economic Importance on Palms in South-East Asia. CABI, Oxford, 1987

[11] B.N. Ang, B. N., U.B. Cheah, and P.S. Chew, - Efficacy and residues of monocrotrophos and methamidophos following trunk injection for the control of Darna trima (Moore) (Lep: Limacodidae), 
a leaf-eating caterpillar of oil palm, || Planter, vol. 73 pp. 303-316, 1998

[12] S. Siburat, and P. Moijun, 1998, - Incidence of leaf-eating caterpillars and control in PPBOP (Sabah) II, Planter 74:421 - 433, 1998

[13] D.W. Roberts, JR Fuxa, R. Gangler, R. Jaques and J. Maddox, Uses of pathogens in insect control. Handbook of Pest Management in Agriculture. 2nd ed. D. Pimentel, Ed. Boca Ratoon, CRC Press, 1991.

[14] M.R. Faria, and S.P. Wright, - Mycoinsecticides and mycoacaricide: a comprehensive list with world wide c overage and international classification of formulation types, || Biol. Contol, vol. 43 pp. 237256, 2007

[15] C.J. Lomer, R.P. Bateman, D. Dent, H. De-groote, O.K. DouroKpindou, C., Kooyman, J. Langewald, Z. Ouambama, R. Peveling, M. and Thomas, - Development of strategies for the incorporation of biological pesticides into the integrated management of locust and grasshoppers, || Agric. Bur. Entomol vol. 1 pp. 71-88, 1999.

[16] M.B. Thomas, -Ecological approaches and the development of truly integrated pest management —. Proc. Natl. Acad. Sci. USA 96:5944$5951,1999$.

[17] L.A. Lacey, R. Frutos, H.K. Kaya, and P. Vail, - Insect pathogens as biological control agents: do they have a future?, \| Biol. Control vol. 21pp. 230-248, 2001
[18] T.D. Hong, R.H. Ellis, and D. Moore, - Development of a model to predict the effect of temperature and moisture on fungal spore longevity, \| Ann. Bot. vol.79 pp.121-128, 1997.

[19] F. Moscardi, - Assessment of the application of baculoviruses for control of Lepidoptera II , Annu. Rev. Entomol., vol. 44pp. 257-289, 1999.

[20] X. Dai, J.P. Hajos, N.N. Joosten, M.M. van Oers, W.F.J. Ijkel, D. Zuiderma, Y. Pang, J.M. and Vlak, - Isolation of a Spodoptera exigua baculovirus recombinant which a $10.6 \mathrm{kbp}$ genome deeltion that retains biological activity $\|$. J.Gen. Virol. Vol. 81 pp. 2545-2554, 2000 .

[21] B.F. McCutchen, P.V. Choudary, R. Crenshaw, D. Maddox, S.G. Kamita, N. Palekar, S. Volrath, F. Fowler, B.D. Hammock, and S. Maeda, - Development of a recombinant baculovirus expressing an insect-selective neurotoxin: potential for pest contro, \| Bio/Technology vol. 9 pp. 848-852, 1991.

[22] B.C. Black, L.A. Brennan, P.M. Dierks, I.E. Gard, 1997. Commercialization of baculovirus insecticides, $\|$ in ed. L.K. Miller,The Baculoviruses. Plenum Press, 341-387., 1997.

[23] S.B. Inceoglu, S.G. Kamita, A.C. Hinton, Q.H. Huang, T.F. Severson, K. Kang, . and B.D. 